\title{
Thiomonas islandica sp. nov., a moderately thermophilic, hydrogen- and sulfur-oxidizing betaproteobacterium isolated from a hot spring
}

Correspondence

Johann Örlygsson

jorlygs@unak.is

\author{
Hildur Vésteinsdóttir, Dagný B. Reynisdóttir and Johann Örlygsson
}

\author{
Faculty of Natural Resource Science, University of Akureyri, Borgir v. Nordurslod, 600 Akureyri, \\ Iceland
}

\begin{abstract}
A novel, hydrogen- and sulfur-oxidizing bacterium, designated strain $6 \mathrm{C}^{\top}$, was isolated from a hot spring in Graendalur, south-western Iceland. Cells of this organism were Gram-reaction-negative, rod-shaped and motile. The strain grew aerobically and was capable of chemolithotrophic growth on thiosulfate and hydrogen, heterotrophic growth on pyruvate, oxalate, acetate and on glutamate in the presence of yeast extract and mixotrophic growth on several organic compounds, thiosulfate and/or hydrogen. During growth on thiosulfate, the final product was sulfate, resulting in a drop in $\mathrm{pH}$ from 6.8 to 2.7. Heterotrophic growth on pyruvate was observed at $\mathrm{pH} 4-7$ (optimum $\mathrm{pH} 4$ ) and $35-50{ }^{\circ} \mathrm{C}$ (optimum $45^{\circ} \mathrm{C}$ ). The DNA G+C content was $65.2 \mathrm{~mol} \%$. As determined by $16 \mathrm{~S}$ rRNA gene sequence analysis, strain $6 \mathrm{C}^{\top}$ represents a distinct species belonging to the class Betaproteobacteria and is most closely related to Thiomonas intermedia DSM $18155^{\top}$ and Thiomonas perometabolis DSM $18570^{\top}$. DNA-DNA hybridization between strain $6 C^{\top}$ and Thiomonas intermedia DSM $18155^{\top}$ and Thiomonas perometabolis DSM $18570^{\top}$ gave relatedness values below $32 \%$. These results, together with physiological characteristics, showed that strain $6 \mathrm{C}^{\top}$ represents a novel species within the genus Thiomonas, for which the name Thiomonas islandica sp. nov. is proposed. The type strain is $6 C^{\top}$ (=DSM $21436^{\top}=J C M$ $\left.16107^{\top}\right)$.
\end{abstract}

The genus Thiomonas was proposed by Moreira \& Amils (1997) to accommodate four former species of the genus Thiobacillus: Thiobacillus cuprinus, Thiobacillus intermedius, Thiobacillus perometabolis and Thiobacillus thermosulfata. This classification was based on their ability to grow chemolithotrophically on reduced sulfur compounds, showing optimal growth under mixotrophic conditions with reduced sulfur compounds (or elemental sulfur) and various organic substrates (Moreira \& Amils, 1997). Recently, two novel species have been assigned to the genus Thiomonas, Thiomonas delicata (Katayama-Fujimura et al., 2006) and Thiomonas bhubaneswarensis (Panda et al., 2009), as well as one species, 'Thiomonas arsenivorans', the name of which has not been validly published (BattagliaBrunet et al., 2006). A suggestion was made by Kelly et al. (2007) that the phylogenetic relationship between Thiomonas cuprina (formerly Thiobacillus cuprinus) and other Thiomonas species should be reassessed. Using full 16S rRNA gene sequence analysis, they revealed that Thiomonas cuprina,

Abbreviations: HOX, hydrogen-oxidizing; SOX, sulfur-oxidizing.

The GenBank/EMBL/DDBJ accession number for the 16S rRNA gene sequence of strain $6 C^{\top}$ is EU625663.

Two supplementary figures are available with the online version of this paper.
Thiomonas delicata and 'Thiomonas arsenivorans' differ in only three nucleotides and are, for that reason, indistinguishable, but are still considered three separate species based on their physiological characteristics.

The first species of the genus Thiomonas were isolated from soils (London, 1963; London \& Rittenberg, 1967). More recently, isolations have been made from mining sites where metals are often present in high concentrations (Dennison et al., 2001; Coupland et al., 2004). Thiomonas cuprina was originally isolated from a uranium mine and is capable of utilizing various sulfide ores (Huber \& Stetter, 1990), whereas other species of the genus Thiomonas are able to oxidize iron (Coupland et al., 2004; Johnson \& Hallberg, 2005) and arsenite (Battaglia-Brunet et al., 2002; Bruneel et al., 2003). Thiomonas thermosulfata (Shooner et al., 1996) and Thiomonas bhubaneswarensis (Panda et al., 2009) are moderate thermophiles and were isolated from sewage sludge and hot-spring sediment, respectively.

In this study, we describe a novel sulfur- and hydrogenoxidizing bacterium that was isolated from a hot-spring in Iceland and propose that it represents a novel species of the genus Thiomonas.

Samples of clayish liquid collected from an off-flow of a hot spring $\left(45^{\circ} \mathrm{C}, \mathrm{pH} 6.6\right)$ were inoculated $(10 \%$, v/v) into 
DSM81 medium, a mineral medium for chemolithotrophic growth, with the addition of $0.1 \mathrm{mg}$ resazurin oxygen indicator $\mathrm{l}^{-1}$. The composition of the medium was as follows $\left(\mathrm{g} \mathrm{l}^{-1}\right): \mathrm{KH}_{2} \mathrm{PO}_{4}$ (2.3), $\mathrm{Na}_{2} \mathrm{HPO}_{4} \cdot 2 \mathrm{H}_{2} \mathrm{O}$ (2.9), $\mathrm{NH}_{4} \mathrm{Cl}$ (1.0), $\mathrm{MgSO}_{4} \cdot 7 \mathrm{H}_{2} \mathrm{O}(0.5), \mathrm{NaHCO}_{3}(0.5), \mathrm{CaCl}_{2} \cdot 2 \mathrm{H}_{2} \mathrm{O}(0.01)$ and ferric ammonium citrate $(0.05)$. A trace element solution was added $\left(5 \mathrm{ml} \mathrm{l}^{-1}\right)$ with the following composition $\left(\mathrm{g} \mathrm{l}^{-1}\right)$ : $\mathrm{ZnSO}_{4} .7 \mathrm{H}_{2} \mathrm{O}(0.1), \mathrm{MnCl}_{2} .4 \mathrm{H}_{2} \mathrm{O}(0.03), \mathrm{H}_{3} \mathrm{BO}_{3}(0.3)$, $\mathrm{CoCl}_{2} \cdot 6 \mathrm{H}_{2} \mathrm{O} \quad(0.2), \mathrm{CuCl}_{2} \cdot 2 \mathrm{H}_{2} \mathrm{O} \quad(0.01), \quad \mathrm{NiCl}_{2} \cdot 6 \mathrm{H}_{2} \mathrm{O}$ (0.02) and $\mathrm{Na}_{2} \mathrm{MoO}_{4} \cdot 2 \mathrm{H}_{2} \mathrm{O}(0.03)$. The cultivation bottles used contained atmospheric air but were pressurized with 101 $\mathrm{kPa}(1 \mathrm{~atm})$ of a $\mathrm{H}_{2}$ and $\mathrm{CO}_{2}$ mixture $(80: 20$, v/v) resulting in a final gas phase of $202 \mathrm{kPa}(2 \mathrm{~atm})$ consisting of $\mathrm{H}_{2} / \mathrm{CO}_{2} /$ $\mathrm{N}_{2} / \mathrm{O}_{2}(40: 10: 40: 10, \mathrm{v} / \mathrm{v})$; the gas was filter-sterilized. The $120 \mathrm{ml}$ bottles contained $20 \mathrm{ml}$ medium. Strain $6 \mathrm{C}^{\mathrm{T}}$ was isolated by using repeated enrichments ( $10 \%$ inoculation, $\mathrm{v} /$ v) and end-point serial dilution. A pure culture of strain $6 \mathrm{C}^{\mathrm{T}}$ was obtained by plating medium from the last bottle in the dilution series on a solid medium. The solid medium was prepared by adding agar $\left(15 \mathrm{~g} \mathrm{l}^{-1}\right)$ to liquid DSM81 medium. After sterilization, the medium was poured into plates, inoculated and incubated in an airtight jar containing the same gas composition as before. The resulting four greyish round colonies $(\sim 1 \mathrm{~mm}$ diameter) were reinoculated into liquid medium and $16 \mathrm{~S}$ rRNA gene sequence analysis was performed. Phase-contrast microscopy and scanning electron microscopy (SEM) were used to examine purity of the cultures and cell morphology. For SEM, the cells were fixed with $2 \%$ glutaraldehyde and dried in ethanol prior to criticalpoint drying. Before examination, the sample was coated with gold. Gram-staining was assayed as described by Smibert \& Krieg (1994) and motility was confirmed by growing the isolate in liquid DSM81 medium under heterotrophic conditions with pyruvate and microscopic examination in a hanging-drop preparation. Cells of strain $6 \mathrm{C}^{\mathrm{T}}$ were Gram reaction-negative, singly occurring, motile rods, $1.7 \mu \mathrm{m}$ long and $0.4 \mu \mathrm{m}$ wide (see Supplementary Fig. S1, available in IJSEM Online).

Growth characteristics were determined from optical density. All experiments were done in duplicate. Experiments to determine the optimum $\mathrm{pH}$ and temperature for growth were performed using the same medium (DSM81) under heterotrophic conditions with $20 \mathrm{mM}$ pyruvate. The experimental bottles were prepared as before and the $\mathrm{pH}$ was adjusted accordingly. For determination of the optimum temperature for growth, the isolate was grown at pH 6.8 and at $20-75{ }^{\circ} \mathrm{C}$. For determination of the optimum $\mathrm{pH}$ for growth, the isolate was grown at $50{ }^{\circ} \mathrm{C}$ and at $\mathrm{pH} 3-10$. The strain grew at $35-50{ }^{\circ} \mathrm{C}$ with optimum growth at $45^{\circ} \mathrm{C}$. No growth was observed at $30{ }^{\circ} \mathrm{C}$ or below or at $55{ }^{\circ} \mathrm{C}$ and higher. The strain was able to grow at $\mathrm{pH} 4-7$ with an optimum of $\mathrm{pH} 4$.

The ability of strain $6 \mathrm{C}^{\mathrm{T}}$ to utilize various substrates heterotrophically was tested by growing the isolate under aerobic conditions at $50{ }^{\circ} \mathrm{C}$ in $5 \mathrm{ml}$ liquid DSM81 medium supplemented with filter-sterilized substrates (final concentration $20 \mathrm{mM}$ or $2 \mathrm{~g} \mathrm{l}^{-1}$ in the case of yeast extract, beef extract, peptone and tryptone). The samples were grown in $23 \mathrm{ml}$ bottles closed with butyl rubber stoppers and aluminium caps. Similar experiments were also done with Thiomonas perometabolis DSM $18570^{\mathrm{T}}$ and Thiomonas intermedia DSM $18155^{\mathrm{T}}$. Substrate utilization was tested in the presence and absence of yeast extract for a cultivation period of 5 days. Growth was monitored by measuring $\mathrm{OD}_{600}$. Growth was observed on pyruvate, oxalate, acetate

Table 1. Characteristics of strain $6 \mathrm{C}^{\top}$ and type strains of other closely related species of the genus Thiomonas

Strain: 1, Thiomonas perometabolis DSM $18570^{\mathrm{T}} ; 2$, Thiomonas intermida DSM $18155^{\mathrm{T}}$. Data for heterotrophic and chemolithotrophic growth was determined in this study. Data on temperatureand $\mathrm{pH}$-dependent growth characteristics as well as DNA $\mathrm{G}+\mathrm{C}$ content for Thiomonas perometabolis DSM $18570^{\mathrm{T}}$ and Thiomonas intermedia DSM $18155^{\mathrm{T}}$ are from Katayama-Fujimura et al. (1983, 1984). All strains were positive for chemolithotrophic growth on sulfur and thiosulfate and negative for heterotrophic growth on formate, propionate, butyrate and crotonate. w, Weakly positive.

\begin{tabular}{|c|c|c|c|}
\hline Characteristic & $6 C^{T}$ & 1 & 2 \\
\hline \multicolumn{4}{|l|}{ Heterotrophic growth on: } \\
\hline Acetate & + & $\mathrm{W}$ & - \\
\hline Pyruvate & + & $\mathrm{W}$ & - \\
\hline Oxalate & + & - & $\mathrm{W}$ \\
\hline Lactate & - & - & + \\
\hline Malate & - & + & + \\
\hline Succinate & - & + & + \\
\hline Aspartate & - & + & + \\
\hline Alanine & - & + & + \\
\hline Glycine & - & + & - \\
\hline Serine & - & + & - \\
\hline Threonine & - & + & - \\
\hline Histidine & - & + & $\mathrm{w}$ \\
\hline Glutamate & $+^{*}$ & + & + \\
\hline Xylose & - & + & + \\
\hline Glucose & - & + & + \\
\hline Mannose & - & + & + \\
\hline Fructose & - & $\mathrm{w}$ & + \\
\hline Sucrose & - & $\mathrm{w}$ & + \\
\hline Galactose & - & $\mathrm{W}$ & - \\
\hline Yeast extract & - & + & + \\
\hline Peptone & - & + & + \\
\hline Bacto tryptone & - & + & + \\
\hline Beef extract & - & + & + \\
\hline Casamino acids & - & + & + \\
\hline $\begin{array}{l}\text { Chemolithotrophic growth on } \mathrm{H}_{2} \\
\text { Growth temperature }\left({ }^{\circ} \mathrm{C}\right)\end{array}$ & + & - & - \\
\hline Range & $35-50$ & $15-42$ & $15-37$ \\
\hline Optimum & 45 & $35-37$ & $30-35$ \\
\hline \multicolumn{4}{|l|}{ Growth pH } \\
\hline Range & $4.0-7.0$ & $5.0-7.0$ & $5.0-7.5$ \\
\hline Optimum & 4.0 & $5.5-6.0$ & $5.5-6.0$ \\
\hline DNA $G+C$ content $(\mathrm{mol} \%)$ & 65.2 & $65-66$ & $65-67$ \\
\hline
\end{tabular}

${ }^{\star}$ Positive in the presence of yeast extract. 
and on glutamate in the presence of yeast extract (Table 1). No growth was observed on many other compounds, as described in the species description.

Special growth experiments were done under hydrogenoxidizing (HOX), sulfur-oxidizing (SOX) and mixotrophic conditions on pyruvate, hydrogen and thiosulfate. In all cases, growth experiments were done in $120 \mathrm{ml}$ serum bottles with a gas volume of $100 \mathrm{ml}$ and medium (DSM81) volume of $20 \mathrm{ml}$. Growth experiments under HOX conditions were done under conditions used during the isolation of the strain. Hydrogen levels were analysed according to Orlygsson \& Baldursson (2007). After a lag phase of more than $20 \mathrm{~h}$, hydrogen uptake was detected and growth was observed under HOX conditions (Fig. 1a). During the active-growth phase, the strain utilized hydrogen from the gas phase at a rate of $0.17 \mathrm{mmol} \mathrm{H}_{2}$

(a)

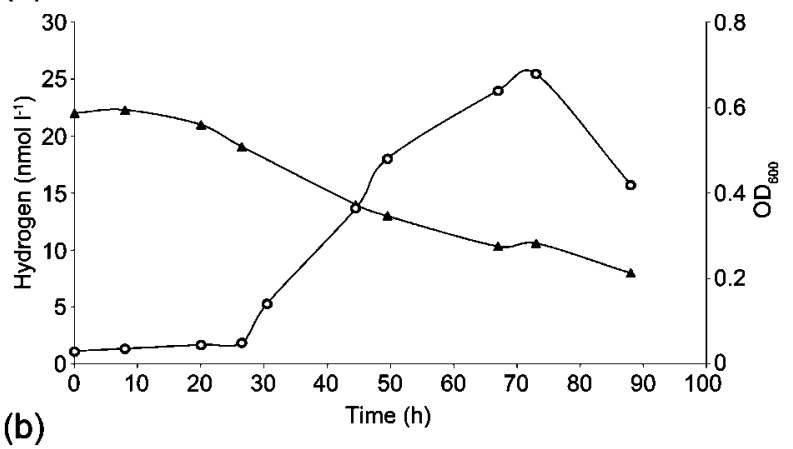

(b)

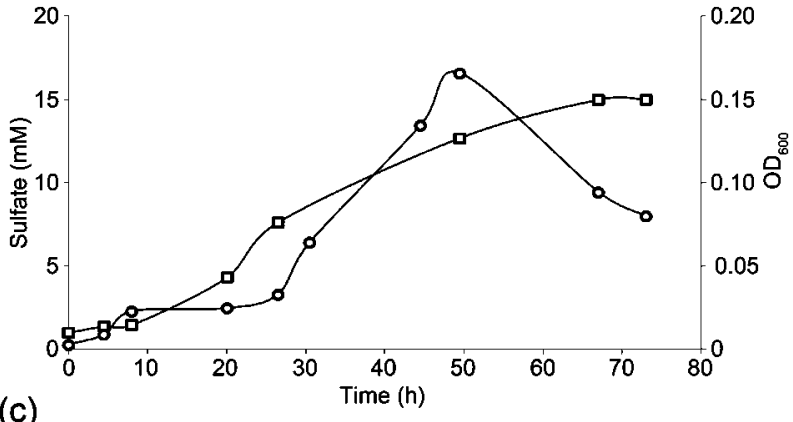

(c)

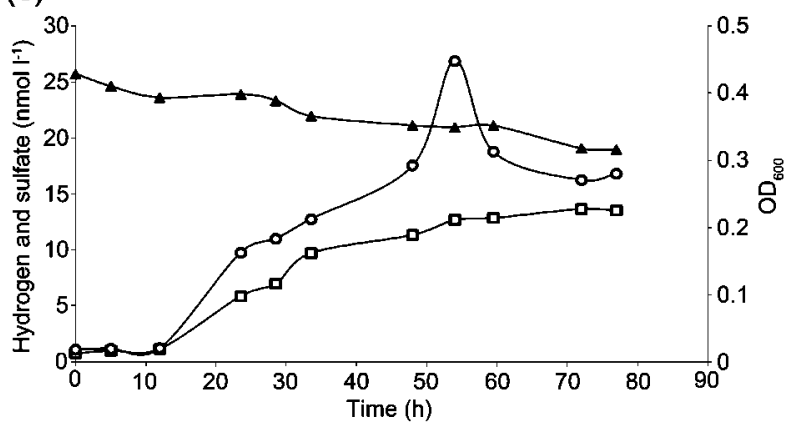

Fig. 1. Growth of strain $6 C^{\top}$ during: $H O X$ conditions (a), SOX conditions (b) and mixotrophic conditions on hydrogen, thiosulfate and pyruvate (c). Plots represent hydrogen level $(\boldsymbol{\Lambda})$, growth $(\bigcirc)$ and sulfate level ( $\square)$. $\mathrm{l}^{-1} \mathrm{~h}^{-1}$ and the concentration of hydrogen dropped from 22.3 to $8.0 \mathrm{mmol} \mathrm{l}^{-1}$. The $\mathrm{pH}$ at the end of the experimental time was 6.5. Growth experiments on thiosulfate (SOX conditions) were performed at $50{ }^{\circ} \mathrm{C}$ using DSM81 medium supplemented with thiosulfate $(40 \mathrm{mM})$. The gas phase had a pressure of $202 \mathrm{kPa}(2 \mathrm{~atm})$ and consisted of $\mathrm{N}_{2} / \mathrm{CO}_{2} / \mathrm{O}_{2}(80: 10: 10, \mathrm{v} / \mathrm{v})$. Growth was measured by monitoring $\mathrm{OD}_{600}$, the levels of sulfate formed and drops in $\mathrm{pH}$ in the medium. The amount of sulfate formed was determined according to Tabatabai (1974). A similar lag phase was observed, as under HOX conditions (Fig. 1b). Growth was observed under SOX conditions but the increase in biomass $\left(\mathrm{OD}_{600}\right)$ was much less pronounced than that of cultures grown under HOX conditions. The end product of thiosulfate oxidation was sulphate, which accumulated to $14.6 \mathrm{mM}$, with a drop in $\mathrm{pH}$ to 2.7 at the end of the cultivation time.

Growth experiments under mixotrophic conditions were performed using hydrogen, thiosulfate $(40 \mathrm{mM})$ and pyruvate $(20 \mathrm{mM})$ as energy sources and carbon dioxide as the carbon source. Similar growth characteristics were observed to those under SOX conditions and the hydrogen oxidation rate $\left(0.09 \mathrm{mmol} \mathrm{H}_{2} \mathrm{l}^{-1} \mathrm{~h}^{-1}\right.$ from the gas phase) was far slower compared with those observed under HOX conditions only. The final sulfate concentration was similar to that for SOX conditions only, being $13.4 \mathrm{mM}$ at the end of the experimental time with a resulting $\mathrm{pH}$ of 2.6 (Fig. 1c). Additional experiments on the physiological characteristics of the strain under heterotrophic and mixotrophic conditions are presented as supplementary data (see Supplementary Fig. S2a-c).

It has been known for a long time that hydrogen oxidizers are present in various environments (Kaserer, 1906; Ruhland, 1924; Schatz \& Bovell, 1952), but relatively few data have been reported on the hydrogen uptake rates of these bacteria. In the few experiments reported, the culture conditions used were different and are, therefore, not comparable to the data presented in this study. Previous studies in our laboratory have focused on the hydrogen uptake rates of strains Cupriavidus necator (previously Wautersia eutropha) DSM 428, Hydrogenophilus hirschii DSM $11420^{\mathrm{T}}$, Hydrogenobacter hydrogenophilus DSM $2913^{\mathrm{T}}$ and Sulfurihydrogenibium azorense DSM $15241^{\mathrm{T}}$ (data not shown). Compared to these strains, strain $6 \mathrm{C}^{\mathrm{T}}$ had slightly lower hydrogen oxidation rates. During the growth period of strain $6 \mathrm{C}^{\mathrm{T}}$, oxygen was depleted from the culture bottles, which could be observed visibly by the resazurin indicator. The depletion of oxygen and the drop in $\mathrm{pH}$ to 2.7 during both chemolithotrophic (Fig. 1b) and mixotrophic (Fig. 1c) conditions could explain the inability of the strain to utilize the hydrogen added to the bottles completely. This will be addressed in further physiological studies of the strain.

Basic phenotypic characteristics suggest that strain $6 C^{\mathrm{T}}$ belongs to the genus Thiomonas, being Gram-negative, rod-shaped and capable of chemolithotropic (on sulfur 
compounds) and mixotrophic growth. The isolate is, however, phenotypically different in several aspects from all other previously described species of the genus Thiomonas. The major difference is the ability of strain $6 \mathrm{C}^{\mathrm{T}}$ to use hydrogen as an electron donor and energy source. Until now, no other species of the genus Thiomonas have been shown to possess this ability, but the species formerly known as Thiobacillus ferrooxidans (now Acidithiobacillus ferrooxidans) (Kelly \& Wood, 2000) is able to oxidize hydrogen (Drobner et al., 1990). The hydrogen oxidation rates of this species have not, to our knowledge, been determined. It is, however, well known that many sulfur-oxidizing bacteria are capable of hydrogen oxidation (Aragno, 1992). Phenotypic characteristics that differentiate strain $6 \mathrm{C}^{\mathrm{T}}$ from its closest phylogenetic neighbours, Thiomonas intermedia DSM $18155^{\mathrm{T}}$ and Thiomonas perometabolis DSM $18570^{\mathrm{T}}$ are given in Table 1. Strain $6 \mathrm{C}^{\mathrm{T}}$ has a higher optimum temperature $\left(45^{\circ} \mathrm{C}\right.$ compared with $30-35{ }^{\circ} \mathrm{C}$ ) (Katayama-Fujimura et al., 1984 ) and a lower optimum $\mathrm{pH}(\mathrm{pH} 4.0$ compared with $\mathrm{pH}$ 5.5-6.0) for growth compared with Thiomonas intermedia DSM $18155^{\mathrm{T}}$ and Thiomonas perometabolis DSM $18570^{\mathrm{T}}$ (Katayama-Fujimura et al., 1984). Thiomonas intermedia DSM $18155^{\mathrm{T}}$ and Thiomonas perometabolis DSM $18570^{\mathrm{T}}$ were able to utilize a significantly larger number of carbon substrates than strain $6 \mathrm{C}^{\mathrm{T}}$, which could only grow on acetate, pyruvate, oxalate or on glutamate with the addition of yeast extract (Table 1). There were, however, several discrepancies concerning earlier reports on the carbon degradation capabilities of Thiomonas intermedia DSM $18155^{\mathrm{T}}$ and Thiomonas perometabolis DSM $18570^{\mathrm{T}}$. In the present investigation, Thiomonas perometabolis DSM $18570^{\mathrm{T}}$ showed weak growth on acetate, pyruvate, fructose, sucrose and galactose, which was not observed by Katayama-Fujimura et al. (1983). Thiomonas intermedia DSM $18155^{\mathrm{T}}$ has been reported to be negative for growth on sucrose and positive for growth on serine, contrary to our findings (Table 1). Strain $6 \mathrm{C}^{\mathrm{T}}$ is also phenotypically different and phylogenetically more distant from other species of the genus Thiomonas. Most clearly, the temperature optima are different for all other strains (Huber \& Stetter, 1990; Moreira \& Amils, 1997; Kelly \& Wood, 2005; Kelly et al., 2007; Panda et al., 2009) compared with strain $6 \mathrm{C}^{\mathrm{T}}$. All other strains are mesophiles, except for Thiomonas thermosulfata ATCC $51520^{\mathrm{T}}$, and show much lower temperature optima $\left(20-37^{\circ} \mathrm{C}\right)$. Thiomonas thermosulfata ATCC $51520^{\mathrm{T}}$ has a higher temperature optimum $\left(50.0-52.5{ }^{\circ} \mathrm{C}\right)$ and can grow at up to $65{ }^{\circ} \mathrm{C}$ (Shooner et al., 1996). Thiomonas thermosulfata ATCC $51520^{\mathrm{T}}$ is also distinguished from strain $6 \mathrm{C}^{\mathrm{T}}$ by a lower DNA G + C content (61 mol\%) and by its inability to degrade acetate and pyruvate (Shooner et al., 1996).

For 16S rRNA gene sequence analysis, 1366 unambiguous bases were used. PCR was performed using primers F9 and R1544 (Skirnisdottir et al., 2000), specific for bacterial genes, to amplify $16 \mathrm{~S}$ rRNA genes from DNA. The PCR products were sequenced with universal 16S rRNA primers F9, F515, F1392, R357, F1195 and R1544 by using a BigDye Terminator Cycle Sequencing Ready Reaction kit (Applied Biosystems). Subsequently, the DNA was analysed using a 3730 DNA analyser (Applied Biosystems). The nucleotide sequence was displayed and analysed with Sequencher sequence assembly software (Gene Code Corporation) (Skirnisdottir et al., 2000). Sequences from the 16S rRNA gene sequence analysis were compared to sequences in the NCBI database using the nucleotide-nucleotide BLAST (BLASTN) tool. The Ribosomal Database Project was also used to obtain sequences of related strains. The most similar sequences obtained from the databases were aligned with the sequencing results in the programs BioEdit (Hall, 1999) and CLUSTAL_X (Thompson et al., 1997) where final alignments were performed to generate phylogenetic trees using the TREECON program (Van de Peer \& De Wachter, 1997); this was also used to view the trees. A diverse group of proteobacteria were used as reference species and Pseudomonas aeruginosa strain X06684 was used as an outgroup. Examination of the 16S rRNA gene sequences revealed that strain $6 C^{\mathrm{T}}$ showed 97.5 and $97.4 \%$ 16S rRNA gene sequence similarity to Thiomonas intermedia DSM $18155^{\mathrm{T}}$ and Thiomonas perometabolis DSM $18570^{\mathrm{T}}$,

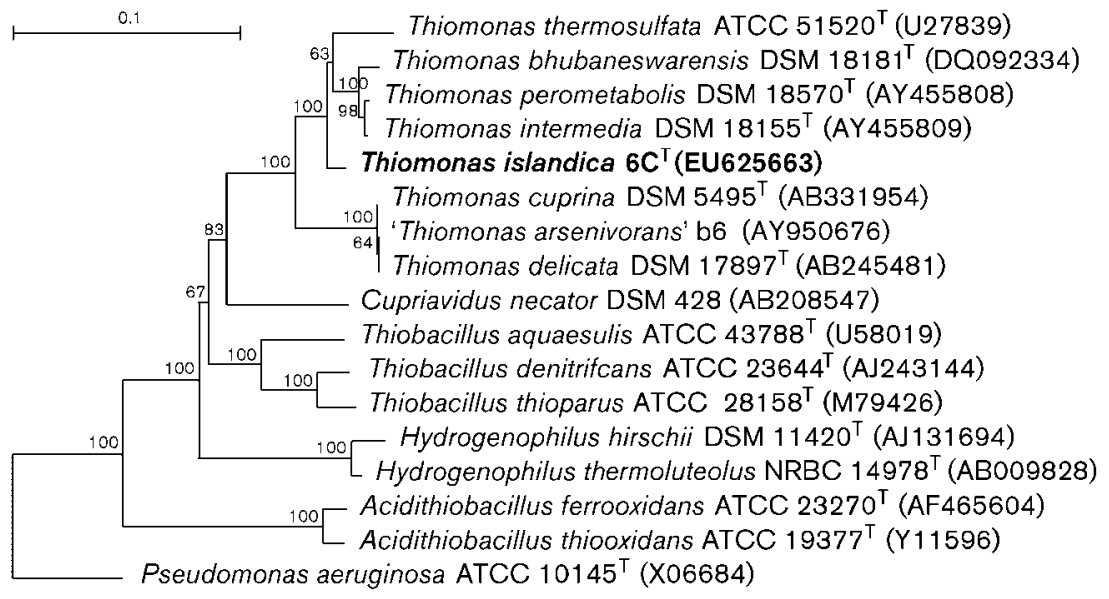

Fig. 2. Phylogenetic tree based on $16 \mathrm{~S}$ rRNA gene sequence comparisons showing the relationship between strain $6 \mathrm{C}^{\top}$ and related type strains. The tree was reconstructed using the neighbour-joining method, following distance analysis calculated by using the Jukes and Cantor method (Jukes \& Cantor, 1969). Bootstrap values greater than $50 \%$ are shown at branching points. Pseudomonas aeruginosa ATCC $10145^{\top}$ was used as an outgroup. Bar, 0.1 substitutions per nucleotide site. 
respectively, with less than $97 \%$ similarity to strains of other species of the genus Thiomonas. The results of the complete $16 \mathrm{~S}$ rRNA gene sequence analysis are presented as a phylogenetic tree (Fig. 2) showing the position of strain $6 \mathrm{C}^{\mathrm{T}}$ within the genus Thiomonas and other closely related species. Together, strain $6 \mathrm{C}^{\mathrm{T}}$, Thiomonas thermosulfata ATCC $51520^{\mathrm{T}}$, Thiomonas bhubaneswarensis DSM $18181^{\mathrm{T}}$, Thiomonas perometabolis DSM $18570^{\mathrm{T}}$ and Thiomonas intermedia DSM $18155^{\mathrm{T}}$ form a subcluster within the genus that branches off above the other two type strains of species of Thiomonas, Thiomonas cuprina DSM $5495^{\mathrm{T}}$ and Thiomonas delicata DSM $17897^{\mathrm{T}}$. Intracluster $16 \mathrm{~S}$ rRNA gene sequence similarity values for strain $6 \mathrm{C}^{\mathrm{T}}$ within the genus Thiomonas ranged from 94.4 to $97.5 \%$. The DNA $\mathrm{G}+\mathrm{C}$ content was analysed by DSMZ using HPLC according to Mesbah et al. (1989) and was $65.2 \mathrm{~mol} \%$, which is similar to that of Thiomonas intermedia DSM $18155^{\mathrm{T}}$ (64.9 mol\%) and Thiomonas perometabolis DSM $18570^{\mathrm{T}}(65.0 \mathrm{~mol} \%)$ (Katayama-Fujimura et al., 1984).

Genomic DNA was isolated using a French pressure cell (Thermo Spectronic) and was purified by chromatography on hydroxyapatite as described by Cashion et al. (1977). DNA-DNA hybridization was carried out, as described by De Ley et al. (1970) and under consideration of the modifications described by Huß et al. (1983), using a Cary 100 Bio UV-Vis spectrophotometer equipped with a Peltier-thermostatted $6 \times 6$ multicell changer and a temperature controller with an in-situ temperature probe (Varian). The results of DNA-DNA hybridization between strain $6 \mathrm{C}^{\mathrm{T}}$ and Thiomonas perometabolis DSM $18570^{\mathrm{T}}$ and Thiomonas intermedia DSM $18155^{\mathrm{T}}$ were $30.6 \%(31.7 \%)$ and $26.8 \%(21.1 \%)$, respectively (values in parentheses are results of measurements in duplicate). Therefore, considering $70 \%$ DNA-DNA relatedness as a cut-off point for species delineation (Wayne et al., 1987), strain $6 \mathrm{C}^{\mathrm{T}}$ should be regarded as representative of a novel species of the genus Thiomonas.

The phylogenetic relationship between strain $6 \mathrm{C}^{\mathrm{T}}$ and other species of the genus Thiomonas and the differences in their physiological properties suggest that strain $6 \mathrm{C}^{\mathrm{T}}$ represents a novel species, for which the name Thiomonas islandica sp. nov. is proposed.

\section{Description of Thiomonas islandica sp. nov.}

Thiomonas islandica (is.lan'di.ca. N.L. fem. adj. islandica Icelandic, describing the place of first isolation).

Cells are straight rods, $1.7 \times 0.4 \mu \mathrm{m}$, occurring singly, motile and Gram-reaction-negative. Growth occurs under aerobic conditions. Colonies grown on solid DSM81 medium are greyish, round and $\sim 1 \mathrm{~mm}$ in diameter. Moderately thermophilic with an optimum temperature for growth of $45^{\circ} \mathrm{C}$. No growth occurs at $30^{\circ} \mathrm{C}$ or below or at $55{ }^{\circ} \mathrm{C}$ and higher. Optimum $\mathrm{pH}$ for growth under heterotrophic conditions is $\mathrm{pH} 4$. Shows heterotrophic, chemolithotrophic and mixotrophic growth properties. Shows heterotrophic growth on acetate, oxalate, pyruvate and on glutamate in the presence of yeast extract. No growth occurs on propionate, butyrate, formate, crotonate, lactate, malate, succinate, aspartate, alanine, glycine, serine, threonine, histidine, xylose, glucose, mannose, fructose, galactose, sucrose, yeast extract, peptone, tryptone, beef extract or Casamino acids. The DNA G $+\mathrm{C}$ content of the type strain is $65.2 \mathrm{~mol} \%$. No growth factors are required.

The type strain, $6 C^{\mathrm{T}}\left(=\mathrm{DSM} 21436^{\mathrm{T}}=\mathrm{JCM} 16107^{\mathrm{T}}\right)$, was isolated from a clayish liquid sample of a hot spring in Graendalur, south-western Iceland.

\section{Acknowledgements}

This work was sponsored by the Nordic Energy Research Fund, the Icelandic Research Fund (Rannís), the Technological Development and Innovation Fund and The Ministry of Industry (The Biotech net).

\section{References}

Aragno, M. (1992). Aerobic, chemolithoautotrophic, thermophilic bacteria. In Thermophilic Bacteria, pp. 77-103. Edited by J. K. Kristjansson. Boca Raton, FL: CRC Press, Inc.

Battaglia-Brunet, F., Dictor, M. C., Garrido, F., Crouzet, C., Morin, D., Dekeyser, K., Clarens, M. \& Baranger, P. (2002). An arsenic(III)oxidizing bacterial population: selection, characterization, and performance in reactors. J Appl Microbiol 93, 656-667.

Battaglia-Brunet, F., Joulian, C., Garrido, F., Dictor, M. C., Morin, D., Coupland, C., Johnson, D. B., Hallberg, K. B. \& Baranger, P. (2006). Oxidation of arsenite by Thiomonas strains and characterization of Thiomonas arsenivorans sp. nov. Antonie van Leeuwenhoek 89, 99108.

Bruneel, O., Personné, J. C., Casiot, C., LeBlanc, M., Poulichet, F. E., Mahler, B. J., Le Fléche, A. \& Grimont, P. A. D. (2003). Mediation of arsenic oxidation by Thiomonas sp. in acid-mine drainage (Carnoulés, France). J Appl Microbiol 95, 492-499.

Cashion, P., Holder-Franklin, M. A., McCully, J. \& Franklin, M. (1977). A rapid method for the base ratio determination of bacterial DNA. Anal Biochem 81, 461-466.

Coupland, K., Battaglia-Brunet, F., Hallberg, K. B., Dictor, M. C., Garrido, F. \& Johnson, D. B. (2004). Oxidation of iron, sulfur and arsenic in mine waters and mine wastes: an important role for novel Thiomonas spp. In Biohydrometallurgy: a Sustainable Technology in Evolution, pp. 639-646. Edited by M. Tsezos, A. Hatzikioseyjan \& E. Remoudaki. Zografou, Greece: Technical University of Athens.

De Ley, J., Cattoir, H. \& Reynaerts, A. (1970). The quantitative measurement of DNA hybridization from renaturation rates. Eur $J$ Biochem 12, 133-142.

Dennison, F., Sen, A. M., Hallberg, K. B. \& Johnson, D. B. (2001). Biological versus abiotic oxidation of iron in acid mine drainage waters: an important role for moderately acidophilic, iron-oxidizing bacteria. In Biohydrometallurgy: Fundamentals, Technology and Sustainable Development, pp. 493-501. Edited by V. E. Ciminelli \& O. Garcia. Amsterdam: Elsevier.

Drobner, E., Huber, H. \& Stetter, K. O. (1990). Thiobacillus ferrooxidans, a facultative hydrogen oxidizer. Appl Environ Microbiol 56, 2922-2923.

Hall, T. A. (1999). BioEdit: a user-friendly biological sequence alignment editor and analysis program for Windows 95/98/NT. Nucleic Acids Symp Ser 41, 95-98. 
Huber, H. \& Stetter, K. O. (1990). Thiobacillus cuprinus sp. nov., a novel facultatively organotrophic metal-mobilizing bacterium. Appl Environ Microbiol 56, 315-322.

Huß, V. A. R., Festl, H. \& Schleifer, K. H. (1983). Studies on the spectrophotometric determination of DNA hybridization from renaturation rates. Syst Appl Microbiol 4, 184-192.

Johnson, D. B. \& Hallberg, K. B. (2005). Biogeochemistry of the compost bioreactor components of a composite acid mine drainage passive remediation system. Sci Total Environ 338, 81-93.

Jukes, T. H. \& Cantor, C. R. (1969). Evolution of protein molecules. In Mammalian Protein Metabolism, vol. 3, pp. 21-132. Edited by H. N. Munro. New York: Academic Press.

Kaserer, H. (1906). Die oxydation des wasserstoffes durch mikroorganismen. Centr Bacteriol Parasitenkd 16, 681-696 (in German).

Katayama-Fujimura, Y., Kawashima, I., Tsuzaki, N. \& Kuraishi, H. (1983). Reidentification of Thiobacillus perometabolis ATCC 27793 and Thiobacillus sp. strain A2 with reference to a new species, Thiobacillus rapidicrenscens sp. nov. Int J Syst Bacteriol 33, 532538.

Katayama-Fujimura, Y., Kawashima, I., Tsuzaki, N. \& Kuraishi, H. (1984). Physiological characteristics of the facultatively chemolithotrophic Thiobacillus species Thiobacillus delicatus nom. rev., emend., Thiobacillus perometabolis and Thiobacillus intermedius. Int J Syst Bacteriol 34, 139-144.

Katayama-Fujimura, Y., Uchino, Y., Wood, A. P. \& Kelly, D. P. (2006). Confirmation of Thiomonas delicata (formerly Thiobacillus delicatus) as a distinct species of the genus Thiomonas Moreira and Amils 1997 with comments on some species currently assigned to the genus. Int $J$ Syst Evol Microbiol 56, 2553-2557.

Kelly, D. P. \& Wood, A. (2000). Reclassification of some species of Thiobacillus to the newly designated genera Acidithiobacillus gen. nov., Halothiobacillus gen. nov., and Thermithiobacillus gen. nov. Int J Syst Evol Microbiol 50, 511-516.

Kelly, D. P. \& Wood, A. (2005). Genus incertae sedis XVIII. Thiomonas Moreira and Amils 1997, 527 VP. In Bergey's Manual of Systematic Bacteriology, 2nd edn, vol. 2C, pp. 757-759. Edited by D. J. Brenner, N. R. Krieg, J. T. Staley \& B. M. Garrity. New York: Springer.

Kelly, D. P., Uchino, Y., Huber, H., Amils, R. \& Wood, A. P. (2007). Reassessment of the phylogenetic relationships of Thiomonas cuprina. Int J Syst Evol Microbiol 57, 2720-2724.

London, J. (1963). Thiobacillus intermedius nov. sp., a novel type of facultative autotroph. Arch Mikrobiol 46, 329-337.

London, J. \& Rittenberg, S. C. (1967). Thiobacillus perometabolis nov. sp., a non-autotrophic Thiobacillus. Arch Mikrobiol 59, 218-225.
Mesbah, M., Premachandran, U. \& Whitman, W. B. (1989). Precise measurement of the $\mathrm{G}+\mathrm{C}$ content of deoxyribonucleic acid by highperformance liquid chromatography. Int J Syst Bacteriol 39, 159-167.

Moreira, D. \& Amils, R. (1997). Phylogeny of Thiobacillus cuprinus and other mixotrophic thiobacilli: proposal for Thiomonas gen. nov. Int $J$ Syst Bacteriol 47, 522-528.

Orlygsson, J. \& Baldursson, S. R. B. (2007). Phylogenetic and physiological studies of four hydrogen-producing thermoanaerobes from Icelandic geothermal areas. Icel Agric Sci 20, 93-105.

Panda, S. K., Jyoti, V., Bhadra, B., Nayak, K. C., Shivaji, S., Rainey, F. A. \& Das, S. K. (2009). Thiomonas bhubaneswarensis sp. nov., an obligately mixotrophic moderately thermophilic, thiosulfate-oxidizing bacterium. Int J Syst Evol Microbiol 59, 2171-2175.

Ruhland, W. (1924). Beitrage zur Physiologie der Knallgasbacterien. Jahrb Wiss Botan 63, 321-389 (in German).

Schatz, A. \& Bovell, C. R. (1952). Growth and hydrogenase activity of a new bacterium, Hydrogenomonas facilis. J Bacteriol 63, 87-98.

Shooner, F., Bousquet, J. \& Tyagi, R. D. (1996). Isolation, phenotypic characterization, and phylogenetic position of a novel, facultative autotrophic, moderately thermophilic bacterium, Thiobacillus thermosulfatus sp. nov. Int J Syst Bacteriol 46, 409-415.

Skirnisdottir, S., Hreggvidsson, G. O., Hjörleifsdottir, S., Marteinsson, V. T., Petursdottir, S. K., Holst, O. \& Kristjansson, J. K. (2000). Influence of sulfide and temperature on species composition and community structure of hot spring microbial mats. Appl Environ Microbiol 66, 2835-2841.

Smibert, R. M. \& Krieg, N. R. (1994). Phenotypic characterization. In Methods for General and Molecular Bacteriology, pp. 607-654. Edited by P. Gerhardt, R. G. E. Murray, W. A. Wood \& N. R. Krieg. Washington, DC: Americal Society for Microbiology.

Tabatabai, M. A. (1974). A rapid method for determination of sulfate in water samples. Environ Lett 7, 237-243.

Thompson, J. D., Gibson, T. J., Plewniak, F., Jeanmougin, F. \& Higgins, D. G. (1997). The CLUSTAL_X windows interface: flexible strategies for multiple sequence alignment aided by quality analysis tools. Nucleic Acids Res 25, 4876-4882.

Van de Peer, Y. \& De Wachter, R. (1997). Construction of evolutionary distance trees with TREECON for Windows: accounting for variation in nucleotide substitution rate among sites. Comput Appl Biosci 13, 227-230.

Wayne, L. G., Brenner, D. J., Colwell, R. R., Grimont, P. A. D., Kandler, O., Krichevsky, M. I., Moore, L. H., Moore, W. E. C., Murray, R. G. E. \& other authors (1987). International Committee on Systematic Bacteriology. Report of the ad hoc committee on reconciliation of approaches to bacterial systematics. Int J Syst Bacteriol 37, 463-464. 